KEN GELDER

\section{the man of}

\section{feeling}

PETER READ

Haunted Earth

University of New South Wales Press,

Sydney, 2003

ISBN 0-86840-726-7

RRP $\$ 39.95(\mathrm{pb})$
Haunted Earth is the third book in a trilogy by eco-historian Peter Read that began with Returning to Nothing: The Meaning of Lost Places (1996). His first book had an interesting but curious point to make: that non-Aboriginal people in Australia could be dispossessed (for example, by losing their property through natural disasters) just as Aboriginal people have been, and that as a consequence of this kind of experience their sense of belonging would in fact be substantially deepened. In this account, non-Aboriginal people seemed to need to be dispossessed in order to claim precisely the kind of intimacy with land felt by Aborigines themselves. To lose a place, in other words, increases one's attachment to it: one belongs properly or authentically only after one has been dispossessed. His point had something strangely and literally postcolonial about it, mapping non-Aboriginal people onto the predicament of Aborigines after colonisation as if their traumas could somehow now be shared. It also offered a pathway for settler Australians to imagine themselves as 'indigenous', sewing an ideology of reconciliation seamlessly together with settler self-legitimisation during the 1990s, especially for those already identified as 'native born'.

The second book in Read's trilogy, Belonging (2000), continued to merge non-Aboriginal and Aboriginal senses of land intimacy, although it occasionally expressed anxieties about the politics of this kind of project. What does it do to the specificity of Aboriginal claims for Native title, for example? Most of Read's nonAboriginal examples were (and still are) farmers, 
pastoralists, cattlemen, rural landowners: how their class—has in common the ability to feel 'Aboriginal' can these people actually be? It deeply. In Read's work class is hardly an issue didn't help to find Read masking the politics of worth reflecting on, and he seems disdainful his predicament by casting their relationship to of sociology. Instead, it is the capacity to feel property as, first and foremost, a matter of deeply about the land that produces the sort of deeply felt emotion. His books are full of 'egalitarianism' he is searching for between people whose relation to land and property is settler Australians and Aboriginal people, as conceived sentimentally and described in order if everyone is (or should be) able to feel this to provoke a sentimental effect. Some readers in equal measure. This is Read's version of may very well shed a tear as they work through reconciliation.

these intimately rendered narratives, and they Sentimentality in the eighteenth century was are no doubt meant to. Read's writing is always projected onto the landscape and linked to the up close and personal, a tribute to just how sublime, all of which are similarly activated in deeply some people actually feel about the land- Read's work where belonging can sometimes scapes they have grown up in and-since their offer its settler-subjects a glimpse of the infinite. dispossession is always temporary (because, But it was also associated with the irrational, of course, they are non-Aboriginal)—continue the supernatural; the sentimental novel and the to inhabit.

Gothic novel developed in tandem. Perhaps

In Read's work, emotion is the key and sen- it isn't surprising, then, that the last book in timent is the logic: he is, to draw on the title to Read's trilogy, Haunted Earth, is utterly prethe Scottish writer Henry Mackenzie's famous occupied with ghosts and apparitions, each of 1771 sentimental novel, a man of feeling. which provokes an emotional/sympathetic Indeed, the eighteenth-century sentimental response. These things seem, in fact, to be all novel offers some instructive comparisons with over the place-and Read spends the book folRead's work. It had tied a character's virtue to lowing them across the length and breadth of his or her capacity to invoke powerfully felt Australia, embarking on a sentimental journey sympathetic emotions-and certainly all of (if I can draw on the title of another eighteenthRead's interviewees are virtuously cast in this century novel) of his very own.

respect. Haunted Earth is structurally similar to The dominant metaphor in Read's writing Mackenzie's novel: in both cases the narrator is depth. Land is never just surface and the listens to the heart-rending stories of others present is never just the (perpetual) present: no (who, in Mackenzie, have also usually lost postmodernity here. Belonging is always an something). Emotion in the sentimental novel expression of one's attachment to history, colwas seen as something good in itself, its own onial as well as precolonial, and the deeper that reward. But it also produces a kind of egali- attachment, the better. Read's influences include tarianism, since everyone-no matter what John Mulvaney on Australian prehistory and 
Tom Griffiths's work on Australian antiquarian- to rest. Read gives us one version of this renism. This country is therefore made to seem as dition since many of the ghosts his interviewees if it is, and has always been, extremely old: all see are Aboriginal and always from the distant the more reason to belong to it. Indeed, the past. A true believer, Read never actually sees virtuousness of Read's work lies precisely in the an apparition himself, even though he begins way that it utterly respects its elders-the poets his book in a cemetery and is more concerned he quotes from, the commentators he uses, the with excavating the buried past than anyone he 'venerable' characters he meets, and so on. (No talks to. Many of his interviewees, however, are one is ever criticised here.) Read's first two better placed as mediums. The 'native born' books in this trilogy had been about how to live are the privileged species ('Those of use who in this antiquarian continent, where one is sup- are born here ...'), able to 'feel' the deep conposed to be in constant communion with deep nections to colonial and precolonial pasts as history as if Australia's past is never meant to be they watch Aboriginal apparitions walking forgotten. But in his third book, what is exca- across their property. We might think that vated from the depths is now entirely spectral. seeing a ghost on one's property would be For Read, Australia is 'inspirited': you can unsettling, a reminder of previous land ownerhardly move without falling over a ghost. Of ship, perhaps. But in Read's book, these sightcourse, not everyone sees them, and Read takes ings paradoxically confirm the sense that the a few moments to berate those of us (the new owners belong to their properties. Seeing 'secular', the sceptical) who aren't blessed with an Aboriginal ghost, for Read, legitimates postthis particular gift. But there they are, and there colonial settler ownership; it is itself an act of is no convincing Read otherwise. reconciliation, which in this context always

The notion that Australia is 'haunted' has its means reconciling settler Australians to property. precursors, of course: think of the late colonial (The ghost of a settler Australian might therenovelist Rosa Praed, or the spiritualist-feminists fore be more disturbing, but no one seems to of the 1890s. Think also of Sir Arthur Conan see any of these.)

Doyle, who lectured on spiritualism and ghosts Read is, relative to most Australian historians, while on tour in Australia in the early 1920s. an eccentric, following in the wake of Australian The sense of a spectral Australia is carried on landscape and religious poets, the anthems of through a minor tradition of ghost stories here bush nationalism and the imaginings of 'white which Read seems unaware of, and in the Aboriginality', and sitting alongside contemoccasional postcolonial renditions which sug- porary expressions of eco-spirituality and the gest that contemporary Australia is haunted by Jungian and New Age prophetics of someone its colonial misdeeds—and will remain so until like David Tacey. But he has also placed himself reconciliation and an apology from a prime at the heart of a national project: the justifiminister somehow manage to lay these things cation of settler ownership of Australian land in 
the context of the official policy (albeit more or Aboriginal lore, but again there are monks who less abandoned by the Howard government) of seem to refuse to be assimilated. Muslim immireconciliation. His nationalism makes him talk grants in Burra in South Australia are equally up the 'uniqueness' of the Australian settler obstinate, recognising 'nothing sacred here'. experience. But his liberalism requires that he (241) The refusal to assimilate, or even to be acknowledge other kinds of settlers, not just diasporic, irritates him.

the 'native born'. So Haunted Earth locks itself These examples are fleeting, however: a into a second national project, multicultural- reminder that authentic reconciliation, for ism. Its encounters with established white rural Read, is still something to strive for if only these landowners are thus peppered with immigrant newer arrivals would allow themselves to be stories in a way that reminded me of Murray enlightened (and, we might say, overdeterBail's novel Eucalyptus (1998)—not least mined). His final interviewee, a Japanese man because in both cases, those immigrant stories who is an anthropologist researching traditional are both obsessively related and repeatedly Aboriginal forms of food production, allows enclosed within a nationalist frame. The prob- Read to return to the spiritual realm where lem for Read is how can new immigrants also logic and reason 'seemed less important, even deeply belong to Australia? Since he now con- irrelevant' (253) as the new is smoothly reconceives of belonging in spiritual (or spiritualist) ciled with the old, the immigrant with the terms, his immigrant interviewees are usually indigenous. Haunted Earth is a book with one non-secular: a Buddhist monk, a Malaysian idea, to which each different interviewee is Chinese Taoist, and so on. Read knows that relentlessly subordinated. In this respect, it these people cannot be 'indigenous' in the way is pure ego: indeed, its concept of deep belonghe intends, so his strategy is to universalise ing has something pre-Oedipal about it, as if their experience: they may not quite fit the the child-settler and the nurturing mothernationalist paradigm, but they are nevertheless landscape have never really been separated at 'similar'. Two of his ANU colleagues, Jacqui Lo all. In Returning to Nothing, the settler experiand Dipesh Chakrabarty, are identified in the ence of dispossession only intensified one's same way, their exotic 'rituals' wisely under- sense of attachment, as I noted: one would stood by Read as part of the universal sameness always expect, inevitably, to return to one's of spiritual life. But other interviewees are more property, to come home. At one point, as he troubling. At a Spanish Benedictine monastery walks around his cemetery looking for ghosts, in Western Australia, Read seems exasperated: Read stumbles across a man sleeping: 'For God's 'Some of the monks I speak to hold no idea of sake, what's that? A pair of sneakers, a jacket and the connections between spirituality and the a long shape prone on a double grave ... Someland ... It's not what I expected.' (184) Else- one asleep! I think. Switch off the torch, retreat, where, Read tries to 'harmonise' Buddhist and quietly but fast, and take another direction!' 
(33) This passage is nothing less than symptomatic: homelessness does indeed have no part to play in Read's Australia.

KEN GELDER is Reader in English at the University of Melbourne, Australia. His books include Reading the Vampire (1994) and Uncanny Australia (1998, with Jane M Jacobs). His new book, Popular Fiction: The Logics and Practices of a Literary Field, was published by Routledge at the end of 2004. 